\title{
Moe: nog veel te begrijpen
}

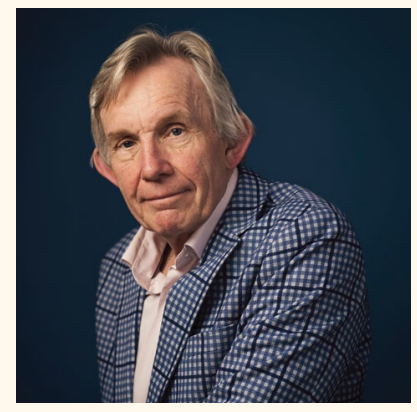

Wim Otto

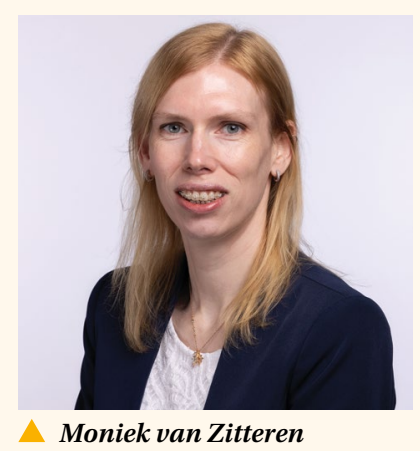

Moniek van Zitteren
Zoals de pandemie de afgelopen twee jaar haast overal de planning in de war heeft geschopt, is dat ook het geval voor het TBV-congres en bijbehorend themanummer. Niet in november, maar in maart.

En wat voor thema zou na twee jaar corona passender kunnen zijn dan vermoeidheid. Dan hebben we het niet over 'coronamoe' zijn of de mentale uitputtingsslag die velen ten gevolge daarvan hebben ervaren, maar over de belangrijke vraag: is aanhoudende moeheid na covid-19 iets nieuws of een oud fenomeen in een nieuwe jas? De neiging bestaat om er een variant van het chronischevermoeidheidssyndroom (CVS) in te zien. De Gezondheidsraad stelt dat de medisch beoordelaar CVS dient te erkennen en functionele beperkingen aan moet nemen. Een uitdaging, gezien de veelzijdigheid van dit ziektebeeld en de (ongewenste) interdoktervariatie die dit oplevert in sociaalmedische beoordelingen, vooral als het om de duurbelastbaarheid gaat.

Dit nummer laat zien dat chronische vermoeidheid meer is dan alleen CVS. Wat te denken van hinderlijk geluid op de werkvloer? Een omgeving zonder onnodig storend of hinderlijk geluid leidt tot minder belasting van onze hersencapaciteit en daardoor tot minder vermoeidheid en een betere kwaliteit van leven. Zo eenvoudig kan het dus zijn.

Of neem licht traumatisch hersenletsel. Door langdurige vermoeidheid te zien als een verstoring van het (mentale) evenwicht, is het mogelijk zicht te krijgen op instand-

houdende factoren.

Cognitieve vermoeidheid lijkt een neerwaartse spiraal: als gevolg van aanhoudende mentale inspanning die nodig is voor een optimale taakuitvoering. Die extra benodigde mentale inspanning resulteert vervolgens in lagere taakprestaties en vereist weer meer mentale inspanning.

En hoe zit het nu met chronische vermoeidheid zonder dat er een relatie kan worden gelegd met andere pathologie? Een bedrijfsarts berichtte ons dat hij na doorvragen bij long-covidpatiënten vaak een burn-out kon vaststellen. Daarmee hebben we medisch gezien misschien nog niets verklaard, maar we weten wel aan welke knoppen we moeten draaien om aan herstel te werken. En dat zijn in het algemeen geen medische interventies!

Opvallend is dat in wetenschappelijk onderzoek vaak de focus wordt gelegd op hetgeen nog niet verklaard is. Karen Nieuwenhuijsen komt tot de conclusie dat er juist al veel bekend is over bijvoorbeeld burn-out. Daarom wil zij bestaande kennis vooral voor preventieve doeleinden benutten. De zeepkist op TBV-online.nl pleit ook voor een preventieve aanpak door middel van vroegsignalering. Daarbij is een belangrijke rol weggelegd voor werkgevers en leidinggevenden om tijdig signalen van ongezonde vermoeidheid op te sporen.

Op TBV-online kunt $u$ nog meer informatie over chronische vermoeidheid en burn-outgerelateerde zaken vinden, waaronder een interview met de onlangs gepromoveerde Kristel Weerdesteijn en een bespreking van haar proefschrift.

Resumerend op de inhoud van dit nummer komt chronische vermoeidheid bij een breed scala aan ziektebeelden voor. Rode draad daarin lijkt dat (langdurige) overbelasting, daarmee samenhangende (over)compensatie en onvoldoende recuperatie resulteren in chronische vermoeidheid. De gevolgen van langdurig compenseren worden vaak onderschat. 